\title{
Growth curve of Atlantoscia floridana (van Name) (Crustacea, Isopoda, Philosciidae) from a Brazilian Restinga Forest ${ }^{1}$
}

\author{
Paula Beatriz Araujo ${ }^{2} \&$ Georgina Bond-Buckup ${ }^{2}$
}

\author{
${ }^{1}$ Contribution number 386 of the Department of Zoology, Universidade Federal do Rio Grande do Sul. \\ 2 Departamento de Zoologia, Programa de Pós-graduação em Biologia Animal, Instituto de Biociências, Universidade Federal \\ do Rio Grande do Sul. Avenida Bento Gonçalves 9500, prédio 43435, 91501-970 Porto Alegre, Rio Grande do Sul, Brasil. E- \\ mail: pbaraujo@portoweb.com.br
}

\begin{abstract}
The terrestrial isopod Atlantoscia floridana (van Name, 1940) occurs from the U.S.A. (Florida) to Brazil and Argentina. In the southernmost Brazilian State, Rio Grande do Sul, the species is recorded in many localities, in urban and in non-urban areas. The growth curve of Atlantoscia floridana based on field data is presented. The specimens were sampled from April, 2000 to October, 2001 at the Reserva Biológica do Lami (RBL), Rio Grande do Sul. Captured individuals were sexed and had their cephalothorax width measured, with the data analyzed with von Bertalanffy's model. The growth curves for males and females are described, respectively, by the equations: $W_{t}=1.303\left[1-\mathrm{e}^{-0.00941(\mathrm{t}+50.37)}\right]$ and $\mathrm{W}_{t}=1.682\left[1-\mathrm{e}^{-0.00575(\mathrm{t}+59.13)}\right]$. The curves showed differential growth between sexes, where females reach a higher $\mathrm{W}_{\alpha}$ with a slower growth rate. Based on the growth curves it was also possible to estimate life expectancy for males and females.
\end{abstract}

KEY WORDS. Growth curve, Oniscidea, terrestrial isopod, Southern Brazil.

\begin{abstract}
RESUMO. O isópodo terrestre Atlantoscia floridana (van Name, 1940) ocorre desde os Estados Unidos (Flórida) até o Brasil e Argentina. No Rio Grande do Sul a espécie é registrada em muitas localidades, em áreas urbanas e nãourbanas. Este trabalho apresenta a curva de crescimento de Atlantoscia floridana, baseada em dados de campo. Os espécimes foram amostrados desde abril, 2000 a outubro, 2001 na Reserva Biológica do Lami (RBL), Rio Grande do Sul. Os indivíduos capturados foram sexados e tiveram o cefalotórax medido. Os dados foram analisados utilizando-se o modelo de von Bertalanffy. A curva de crescimento para machos e fêmeas são descritas, respectivamente, pelas equações $W_{t}=1.303\left[1-\mathrm{e}^{-0.00941(t+50.37)}\right]$ e $W_{t}=1.682\left[1-\mathrm{e}^{-0.00575(t+59.13)}\right]$. As curvas mostraram crescimento diferencial entre os sexos, onde as fêmeas atingem o maior $\mathrm{W} \mu$ com uma taxa de crescimento menor. Com base nas curvas de crescimento também foi possível estimar a expectativa de vida para machos e fêmeas. PALAVRAS CHAVE. Curva de crescimento, isópodo terrestre, Oniscidea, sul do Brasil.
\end{abstract}

The genus Atlantoscia Ferrara \& Taiti, 1984, includes the species $A$. floridana (van Name, 1940) and A. rubromarginata Araujo \& Leistikow 1999. The latter species is only known from the State of Sergipe, Northeastern Brazil, where it is found in litter and bromeliads in the Atlantic Forest (Araujo \& Leistikow 1999). On the other hand, A. floridana occurs in U.S.A. (Florida), Brazil (especially in the coastal States and Trindade and Abrolhos islands), Argentina, and Ascension and Santa Helena islands (Ferrara \& Taiti 1981, Lemos de Castro 1985, Leistikow \& Wägele 1999). In the southernmost Brazilian State, Rio Grande do Sul, the species is recorded in many localities, including urban areas, where it can also be found in litter and bromeliads (ARAujo et al. 1996). While common and abundant species in Brazil there is no information on its ecology. However, important studies have been developed for other philosciid species, e.g.
Philoscia muscorum Scopoli, 1763 (Sutton 1968, 1970, SunderLAND et al. 1976) and Burmoniscus ocellatus (Verhoeff, 1928) (MA et al. 1991).

Von Bertalanffy's growth curve (VON BerTALANFFy 1938), although commonly used for fishes (SANTOS 1978) and for a variety of crustaceans, especially decapods (Fontoura 1989, VAlenti et al. 1994, Barros \& Fontoura 1996, Bueno et al. 2000, Noro \& Buckup 2003) has rarely been used for terrestrial isopods. McQueen \& CARNIO (1974) studied the growth of Porcellio spinicornis Say, 1818 using von Bertalanffy's model, reformulated to consider growth measured in terms of weight. Based on laboratory data HADDAD \& VERANI (1984) presented figures on the body length growth of Balloniscus sellowii (Brandt, 1833), a native South American species.

The Reserva Biológica do Lami is a mosaic of different 
habitats, including restinga forests, sandy plains, dry and wet grasslands, wetlands with shrub or herb layers and Juncus-dominated shoreline vegetation. Four species of terrestrial isopods have been recorded occurring especially in the areas of restinga forest: Balloniscus sellowii, Neotroponiscus daguerrei (Giambiagi de Calabrese, 1939), Trichorhina argentina, Vandel 1963, and $A$. floridana, which is the most abundant.

Since terrestrial isopods are, in general, beneficial because of their role in enhancing nutrient cycling (Paoletti \& HassaL 1999) and also because they are a food source for a wide range of other invertebrates and vertebrates, specific knowledge on their biology in a reserve area is also an important tool for ecological monitoring and conservation. In this paper we present the growth curve of $A$. floridana based on field data.

\section{MATERIAL AND METHODS}

The study was carried out in Reserva Biológica do Lami $(\mathrm{RBL})$, within the area of Porto Alegre City $\left(30^{\circ} 15^{\prime} \mathrm{S} 51^{\circ} 05^{\prime} \mathrm{W}\right)$, Rio Grande do Sul State, Brazil (Fig. 1). The total area of the Reserve comprises 200.6 ha. According to Meira \& Porto (1998) the characteristic vegetation is restinga forest, from 5 to $10 \mathrm{~m}$ tall, with orchids and bromeliads as epiphytes, along with cactuses and the endemic gymnosperm Ephedra tweediana Fish \& C.A. Mey. Grass and sparsely distributed herbs cover the soil and minimize temperature variation when compared to uncovered areas.

Samples of leaf litter were taken monthly, from April, 2000 to October, 2001, along a footpath on a restinga forest area of approximately $12 \times 66 \mathrm{~m}$. Samples were transported in a plastic bag to the laboratory, where specimens of $A$. floridana were collected by hand. Field samples were further sorted out with a Berlese Funnel for more that $72 \mathrm{~h}$ to extract the remaining specimens.

Animals were separated by sex and stage of sex differentiation (adults and mancas). Following SuTTON (1968), instead of body length the cephalothorax-width of the animals extracted was measured, using a stereomicroscope Zeiss Stemi V8 with a micrometer eyepiece. The measurements refer to the greatest width in the horizontal plane of the animal, in dorsal view at the level of the eyes, including the eyes (SunderLand et al. 1976).

The growth of males and females was estimated separately from the displacement of the monthly modes from the frequency distribution by class interval of cephalothorax width. For both males and females a size of $0.488 \mathrm{~mm}$ was used as the mean size of manca II (M II), the second stage after birth (see discussion). All the intramarsupial mancas released by the ovigerous females when put in alcohol were included and considered as part of the monthly recruitment. All the manca stages belong to the first class interval (Figs 2 and 3), which represents the total number of individuals that cannot be identified as males or females.

The mathematical model used was that of von Bertalanffy (1938): $\mathrm{Wt}=\mathrm{W}_{\infty}\left[1^{-\mathrm{e}-\mathrm{k}\left(\mathrm{t}-\mathrm{t}^{\circ}\right)}\right]$, where $\mathrm{Wt}$ is the mean cephalotho-

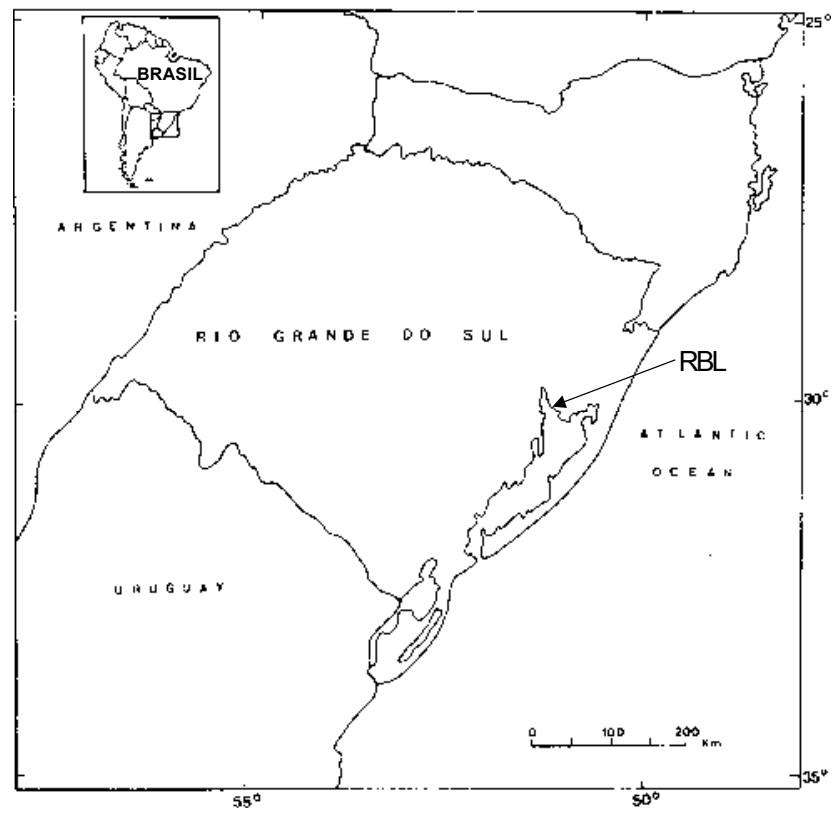

Figure 1. Map of Rio Grande do Sul showing the Reserva Biológica do Lami (RBL), the site of sampling.

rax width, in millimeters, of the individuals at age $t ; \mathrm{W}_{\infty}$ is the maximum mean cephalothorax width, in $\mathrm{mm}$; $\mathrm{k}$ is the parameter related to growth rate; $t$ is the age in days and to is a parameter related with the time at birth.

To calculate $\mathrm{W}_{\infty}, \mathrm{k}$ and to, the following equations were used (FABENS 1965): $\mathrm{t}_{\mathrm{o}}=\mathrm{k}^{-1} \cdot \ln \left[\left(\sum\left(\mathrm{W}_{\infty}-\mathrm{W}_{\mathrm{t}}\right) \cdot \mathrm{e}^{(-\mathrm{kt})} / \sum \mathrm{W}_{\infty} \cdot \mathrm{e}^{(-2 \mathrm{kt})}\right]\right.$ $\mathrm{W}_{\infty}=-\mathrm{a} / \mathrm{b} ; \mathrm{k}=-\mathrm{b}$; where "a" and " $\mathrm{b}$ " are parameters of the linear regression transformed by the method of Ford-Walford (WALFORD 1946) for unequal time interval among samples.

The growth curve obtained for males and females was linearized (AlLEN 1976): $\mathrm{W}_{\mathrm{t}}=\mathrm{a}-\mathrm{b} \cdot \mathrm{r}^{\mathrm{t}}$, where: $\mathrm{a}=\mathrm{W}_{\infty} ; \mathrm{b}=\mathrm{W}_{\infty} \cdot \mathrm{e}^{\mathrm{kt}{ }^{\mathrm{o}}}$; $\mathrm{r}$ mean $=\left(\mathrm{e}^{-\mathrm{k}}\right.$ male $+\mathrm{e}^{-\mathrm{k}}$ female $) / 2$.

In the transformation the dependent variable was calculated using the data obtained from the growth curves. The linear regressions were compared through ANCOVA, with a confidence interval of 95\% (SNEDECOR \& COCHRAN 1967).

\section{RESULTS AND DISCUSSION}

The frequency distributions of the cephalothorax width for both males and females (Figs 2 and 3 ) have several modes, and indicate the coexistence of individuals of varying ages. Although the samples were taken in the period between Apri, 2000 and October, 2001, the frequency distributions refer only to periods from which modes could be obtained for males and females, respectively. Analyzing the mode charts with respect to time, it is possible to observe a mode displacement. The modes chosen were those that after the transformation (WALFORD 1946) had the higher correlation coefficients and also 

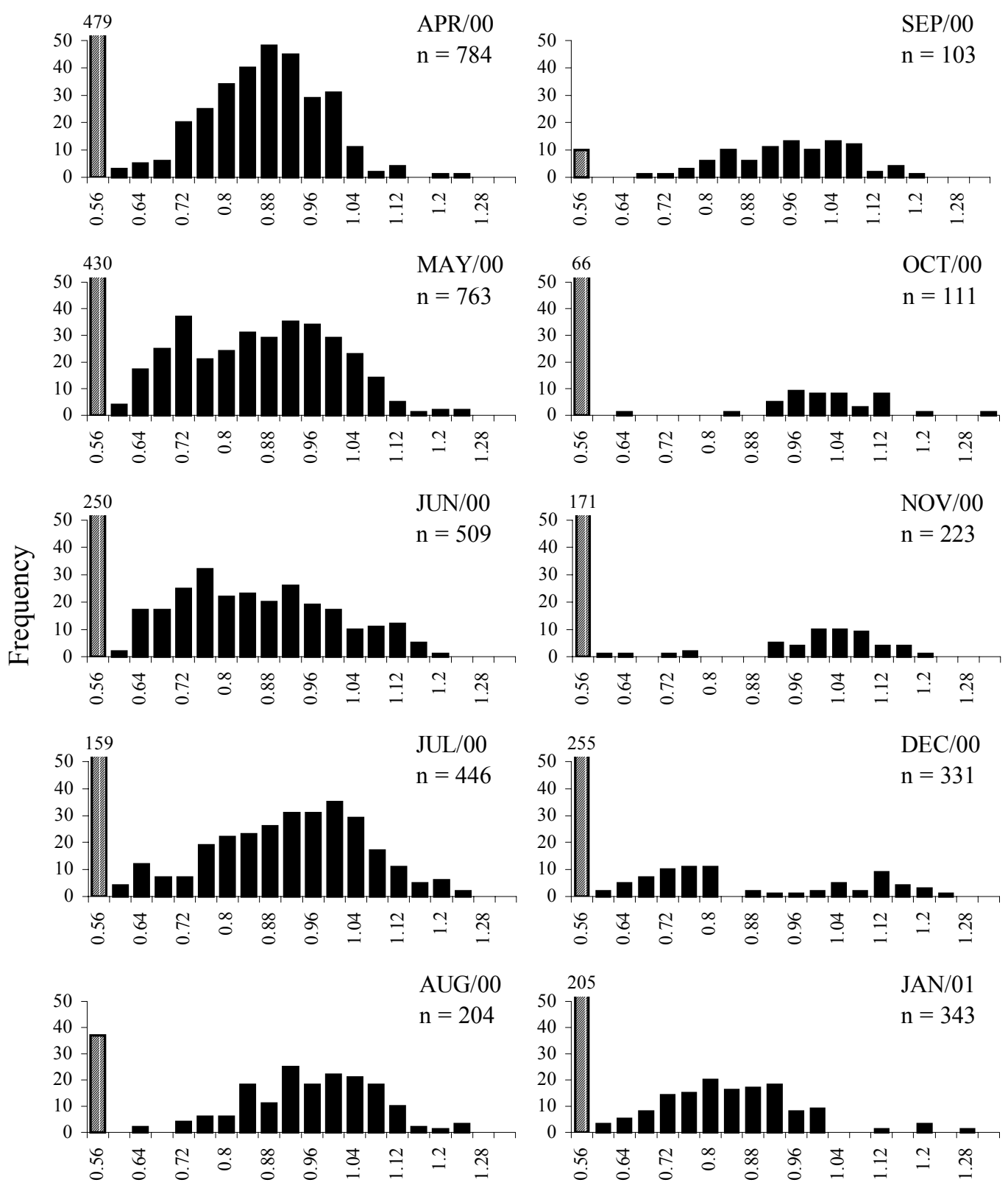

mancas males Cephalothorax width classes (mm)

Figure 2. Atlantoscia floridana, males. Frequency distribution of the cephalotorax width ( $\mathrm{mm}$ ) from April/2000 to January/2001. Values in the abscissa are the upper limit of each class interval.

the best approximation with the values of maximum cephalothorax width obtained in nature. Table I shows the monthly modes chosen for the calculation of the growth curve for males and females.

The growth curves obtained for males and females are shown in figures 4 and 5 , respectively. The equations describ- ing the curves are: males, $W_{t}=1.303\left[1-\mathrm{e}^{-0.00941(t+50.37)}\right]$; females, $\mathrm{W}_{\mathrm{t}}=1.682\left[1-\mathrm{e}^{-0.00575(\mathrm{t}+59.13)}\right]$.

One of the indications that the curves have a correlation with field data is the calculation of $\mathrm{W}_{\mathrm{t}}$ for males and females considering $t=0$. For both sexes, the values obtained are very close to the average values of M II: 0.492 for males 

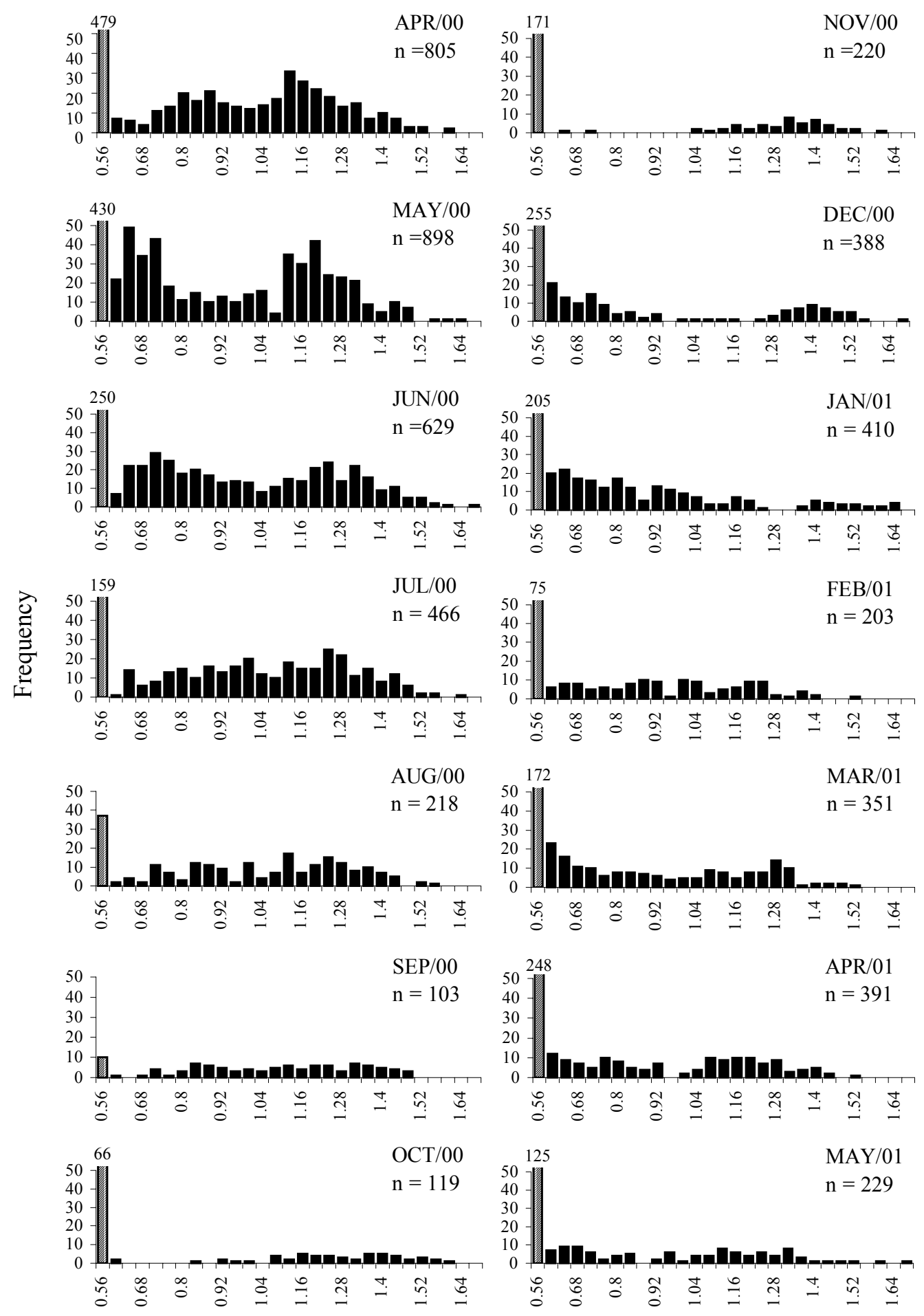

mancas females Cephalothorax width classes (mm)

Figure 3. Atlantoscia floridana, females. Frequency distribution of the cephalotorax width (mm) from April/2000 to May/2001. Values in the abscissa are the upper limit of each class interval.

Revista Brasileira de Zoologia 21 (1): 1-8, março 2004 

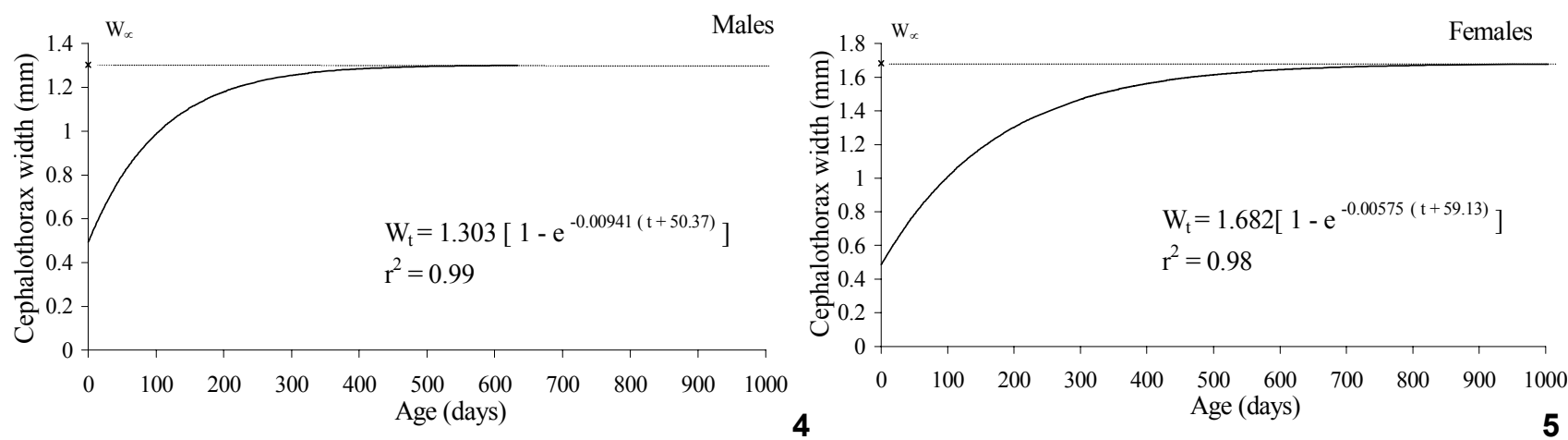

Figures 4-5. Atlantoscia floridana: (4) males, (5) females. Growth curve of cephalothorax width. $W_{t}$ represents the cephalothorax width $(\mathrm{mm})$ of the individuals in time $t, W_{\propto}$ is the cephalothorax maximum mean and $t$ is the age (days). Coefficient of determination from the transformed regression, according to Ford-Walford method (WALFORD 1946).

Table I. Atlantoscia floridana collected in Reserva Biológica do Lami, Porto Alegre, Rio Grande do Sul, from April/2000 to May/2001. Mode values, from which the growth curves of both, males and females, were calculated.

\begin{tabular}{|c|c|c|c|c|c|c|c|c|}
\hline & \multicolumn{5}{|c|}{2000} & \multicolumn{3}{|c|}{2001} \\
\hline & Apr & May & Jul & Sep & Nov & Jan & Feb & May \\
\hline Males & $0.488^{*}$ & 0.696 & 0.976 & 1.136 & - & 1.260 & - & - \\
\hline Females & $0.488^{*}$ & 0.691 & 0.973 & - & 1.383 & - & 1.500 & 1.580 \\
\hline
\end{tabular}

* Mean of cephalothorax width of M II.

and 0.485 for females. Following Araujo et al. (2004), it was used the mean cephalothorax width of M II instead of M I. The M I stage has an approximate duration of $12 \mathrm{~h}$, a very different period from the other stages after the first molt (over nine days). Thus, M I is considered as the final embryonic stage culminating with birth and a molt soon after. Another reason for not using M I is the information in MATSAKIs (1955) that high temperatures can induce the first molt while still inside the marsupium, with the youth being born as M II, at least in Porcellio laevis Latreille, 1804.

Based on the curves it is possible to estimate age from cephalothorax width. Additionally, the curves can help understanding the sexual dimorphism of different patterns in the life cycle. In order to compare growth between the sexes, the curves were linearized. Table II shows the values used for regressions, shown in figure 6 . The results are in table III, where it can be seen that there are no significant differences in homogeneity variance, since $\mathrm{F}_{\mathrm{s}}^{2}<\mathrm{F}_{0.05}, \mathrm{gl} 7.7$. On the other hand, there are significant differences between intercepts, since $F_{a}>$ $\mathrm{F}_{0.05}, \mathrm{gl} \mathrm{1.14}$, and between slopes, $\mathrm{F}_{\mathrm{b}}>\mathrm{F}_{0.05}, \mathrm{gl} 1.15$. There is, therefore, differential growth between the sexes, which indicates that growth in males and females must be treated separately. Females reach greater $\mathrm{W}_{\alpha}$ than males, however with a slower growth rate. If females grow more slowly and for a longer

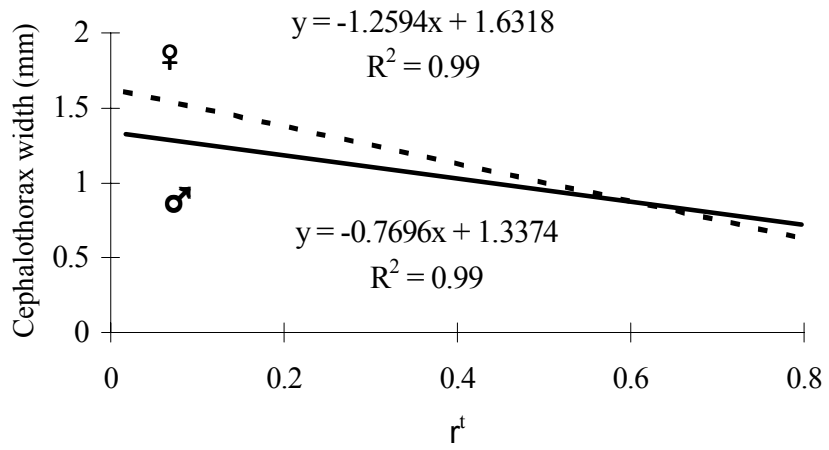

Figure 6. Atlantoscia floridana, males and females. Linearized regression (AlLeN's (1976) method) of the cephalothorax width $(\mathrm{mm})$ in relation to transformed age $\left(\mathrm{r}^{\mathrm{t}}\right)$

Table II. Atlantoscia floridana collected in Reserva Biológica do Lami, Porto Alegre, Rio Grande do Sul, from April/2000 to May/2001. Values of cephalothorax width $(\mathrm{mm})$ and $\mathrm{r}^{\mathrm{t}}$ used to linearize the growth curve of males and females according to AlLEN's (1976) method.

\begin{tabular}{cccc}
\hline \multirow{2}{*}{ Age (days) } & \multirow{2}{*}{$\mathrm{r}^{\mathrm{t}}$} & \multicolumn{2}{c}{ Cephalothorax width $(\mathrm{mm})$} \\
\cline { 3 - 4 } & & Males & Females \\
\hline 30 & 0.7975 & 0.691 & 0.674 \\
90 & 0.5125 & 0.955 & 0.968 \\
120 & 0.4124 & 1.041 & 1.081 \\
180 & 0.2695 & 1.153 & 1.256 \\
210 & 0.2188 & 1.200 & 1.324 \\
365 & 0.0775 & 1.276 & 1.535 \\
430 & 0.0509 & 1.288 & 1.581 \\
550 & 0.0327 & 1.295 & 1.614 \\
600 & 0.0176 & 1.299 & 1.644 \\
\hline
\end{tabular}


Table III. Atlantoscia floridana collected in Reserva Biológica do Lami, Porto Alegre, Rio Grande do Sul, from April/2000 to May/2001. Comparison between linear regressions of cephalotohorax width $(\mathrm{mm})$ and age (days), for males and females. $\mathrm{F}\left(\mathrm{s}^{2}\right)$ : comparison between residual variances; $F$ (a) comparison between intercepts; $F$ (b) comparison between slopes. $\left(^{*}\right) \mathrm{p}<0.05$.

\begin{tabular}{cccc}
\hline Sex & $F(s 2)$ & $F(a)$ & $F(b)$ \\
\hline Male/Female & $F(1.87) N S$ & $F(22.87)^{\star}$ & $F(79.54)^{\star}$ \\
\hline
\end{tabular}

time this provides an advantage in reproductive terms, since they are responsible for egg incubation. The largest male found in the population during the sampled period had a cephalothorax width of $1.30 \mathrm{~mm}$ (sampled in October/2000), which corresponds to a value close to $\mathrm{W}_{\alpha}=1.303$. This suggests that male life expectancy exceeds 600 days (approximately one and a half years), when they reach the average maximum cephalothorax width. The largest female found had $1.68 \mathrm{~mm}$ of cephalothorax width (ovigerous female sampled in May/2001). This value is also close to $\mathrm{W}_{\propto}=1.682$, which confers the females a life expectancy above two years and four months, according to the growth curve obtained. Such longevity is very close to the average longevity known for other species, for example, Trichoniscus pygmaeus Sars, 1899 and T. pusillus (Brandt, 1833) - two years, Philoscia muscorum - two years and three months, Porcellio scaber Latreille, 1804 - three years and Armadillidium vulgare (Latreille, 1804) - 3.5 years (data summarized in SuTTON et al. 1984). In contrast, there are species with shorter longevity, like Hemilepistus reaumuri (Audouin \& Savigny, 1826) - one year, or larger longevity, like Armadillo officinalis Dumeril, 1816 - nine years (data summarized in WARburg 1993).

Other authors have treated the differential growth of males and females. HADDAD \& VERANI (1984) verified a difference in growth from the curves obtained for $B$. sellowii. In this case, males also reach smaller sizes with a higher growth rate. A differential treatment was also given to the growth of Philoscia muscorum by SutTon (1970) and SunderLand et al. (1976), with the latter observing groups with faster or slower growth in each sex. Based on these information we investigated the possibility of more than one growth curve, making clear, for example, differences in growth rate among seasons of the year. Both for males and females only one growth curve was found. If there were more than one curve, clear differences could show up on the first months of post-embryonary development, since HADDAD \& VERANI (1984) found different growth patterns for $B$. sellowii reared in laboratory at room temperature in a region where seasons are marked (Curitiba, Brazil: $25^{\circ} 25^{\prime} \mathrm{S} 49^{\circ} 15^{\prime} \mathrm{W}$ ). On the other hand, seasonal curves could be obtained from laboratory experiments with variable temperatures. HADDAD (1984) conducted laboratory experiments comparing the average time of molting for $B$. sellowii at constant temperatures $\left(25^{\circ} \mathrm{C} \pm 1\right)$ against variable temperatures, related to natural conditions (a natural range of $13^{\circ} \mathrm{C}$ to $28^{\circ} \mathrm{C}$ ). The results show that animals raised on variable temperatures have longer stages during the winter, when the molt frequency is lower. Growth in constant temperatures was uniform. Thus, the growth curves of $A$. floridana obtained from field data describe rates and average stage durations. The generality of the pattern compensates for the seasonal variation, since longevity exceeds one year and all individuals in the population are subjected to the same environmental conditions. During the first year of the sampling period the soil and litter temperature were recorded along the sampling points. The lower temperatures were at about $7^{\circ} \mathrm{C}$ (soil) and $6^{\circ} \mathrm{C}$ (litter) in July; the higher temperatures oscillated at about $25^{\circ} \mathrm{C}$ (soil) and $28^{\circ} \mathrm{C}$ (litter) in March; the average soil temperature was of $18.8^{\circ} \mathrm{C}$ and the average litter temperature of $20.9^{\circ} \mathrm{C}$. The work by NAIR (1998) with Pocellio scaber Latreille, 1804, in Libya, conducted for 50 weeks illustrates this interpretation. The author followed the growth of a group born during the warmer months and another born during the colder ones. A differential growth was found among groups according to temperature, with a slower growth rate for both groups during colder months, irrespective of development stage, and a faster growth rate during warmer months. At the end of the period, both groups reached similar body sizes.

The most frequent widths for males are between 0.72 and $1.04 \mathrm{~mm}$, with a maximum frequency for the $0.88 \mathrm{~mm}$ class. In females, most frequent widths were between 0.64 and $1.32 \mathrm{~mm}$, with a maximum frequency for the $0.64 \mathrm{~mm}$ class. For both sexes there is a strong reduction in the frequencies in the larger classes, in males from the $1.12 \mathrm{~mm}$ class on and in females from the $1.48 \mathrm{~mm}$ class on, which can be a result of mortality in classes corresponding to older individuals. At no time during the sampling period it was possible to observe anything similar to the phenomenon described by WARBURG (1993) of population explosion and migration, with the low number of older individuals probably related to mortality but not to emigration.

The growth curve serves as a reference, supplying information on the growth rate, maximum size attained and the age this size is reached; based on those, the populations could be subject to periodic diagnoses. This kind of information is important in monitoring studies of bioindicator species, not only in terms of abundance levels (Paoletti \& Hassall 1999) but also as a form of accessing the impact of contamination levels on animal growth. Furthermore, it is possible to obtain additional information on growth since it can also be affected by a variety of sources. This is particularly important in reserve areas in order to identify the components that are influencing the populations at a specific time. A. floridana is the most common isopod species in the Reserva Biológica do Lami. It certainly plays an important role not only as part of soil nutrient cycle but also as intermediary hosts for parasites and prey for different animals, particularly vertebrates (Амато et al. 2003). Thus, the knowledge on the population ecology of the isopod species can offer information for monitoring the area as a whole. 


\section{ACKNOWLEDGEMENTS}

The authors wish to thank the Secretaria Municipal do Meio Ambiente (SMAM), especially M.Sc. Rodrigo C. Printes for allowing and supporting our research in the Reserva Biológica do Lami, Aline F. de Quadros, Minnelise M. Augusto and Luis Ernesto C. Schmidt for help on fieldwork, M.Sc. Clarissa K. Noro and Dr Aldo M. de Araujo for discussion, Dr Ludwig Buckup for suggestions and to the PPG-BiologiaAnimal and PROPESQ-UFRGS for financial support.

\section{REFERENCES}

AlleN, R.L. 1976. Method for comparing fish growth curves. New Zealand Journal of Marine and Freshwater Research, Wellington, 10: 687 - 692.

Amato, J.F.R.; S.B. Amato; P.B. Araujo \& A.F. Quadros. 2003. First report of pigmentation dystrophy in terrestrial isopods, Atlantoscia floridana (van Name) (Isopoda, Oniscidea), induced by larval acanthocephalans. Revista Brasileira de Zoologia, Curitiba, 20 (4): 711-716.

Araujo, P.B. \& A. Leistikow. 1999. Philosciids with pleopodal lungs from Brazil, with description of a new species. Contributions to Zoology, Amsterdam, 68 (2): 109-141.

Araujo, P.B.; M.M. Augusto \& G. Bond-Buckup. 2004. Postmarsupial development of Atlantoscia floridana (van Name, 1940) (Crustacea, Isopoda, Oniscidea): the manca stages. Journal of Natural History, London, 38 (8): 951965.

Araujo, P.B.; L. Buckup \& G. Bond-Buckup. 1996. Isópodos terrestres de Santa Catarina e Rio Grande do Sul (Crustacea, Oniscidea). Iheringia, Série Zoologia, Porto Alegre, (81): 111-138.

Barros, M.P. \& N.F. Fontoura. 1996. Crescimento de Potimirim glabra (Kingsley, 1878) (Crustacea, Decapoda, Atyidae) na Praia da Vigia, Garopaba, Santa Catarina, Brasil. Nauplius, Rio Grande, 4: 11-28.

Bueno, A.A.P.; G. Bond-Buckup \& L. Buckup. 2000. Crescimento de Aegla platensis Schmitt em ambiente natural (Crustacea, Decapoda, Aeglidae). Revista Brasileira de Zoologia, Curitiba, 17 (1): 51-60.

Fabens, A.J. 1965. Properties and fitting of the von Bertalanfy growth curve. Growth, Lakeland, 29: 265-289.

Ferrara, F. \& S. Taiti. 1981. Terrestrial isopods from Ascension Island. Monitore Zoologico Italiano, N.S., Florence, 14 (Suppl.): 189-198.

Fontoura, N.F. 1989. Crescimento de Parastacus brasiliensis (von Martens, 1869) (Crustacea, Decapoda, Parastacidae). Revista Brasileira de Biologia, Rio de Janeiro, 49 (4): 897-909.

HADDAD, M.A. 1984. Estádios do desenvolvimento pós-marsupial de Balloniscus sellowii (Brandt, 1833) (Isopoda, Oniscoidea). Dusenia, Curitiba, 13 (3): 135-143.

Haddad, M.A. \& L.C. Verani. 1984. Crescimento pós-marsupial de Balloniscus sellowii (Brandt, 1833) (Isopoda, Oniscoidea). Dusenia, Curitiba, 14 (4): 197-209.

Leistikow, A. \& J.W. WäGele. 1999. Checklist of the terrestrial isopods of the new world (Crustacea, Isopoda, Oniscidea). Revista Brasileira de Zoologia, Curitiba, 16 (1): 1-71.

Lemos de CASTRO, A. 1985. Considerações sobre Atlantoscia alceui Ferrara \& Taiti, 1981 (Isopoda, Oniscoidea, Philosciidae). Revista Brasileira de Biologia, Rio de Janeiro, 45 (4): 417 422.

Ma, H.H.T.; P.K.S. Lam \& D. Dudgeon. 1991. Inter and intraspecific variation in the life histories of three sympatric isopods in a Hong Kong forest. Journal of Zoology, London, 224: 677-687.

Matsakis, J. 1955. Contribution a l'etude du développement postembryonnaire et de la croissance des Oniscoides. Bulletin de la Societé Zoologique de France, Paris, 80: 5265.

McQueEn, D.J. \& J.S. Carnio. 1974. A laboratory study of the effects of some climatic factor on the demography of the terrestrial isopod Porcellio spinicornis Say. Canadian Journal of Zoology, Ottawa, 52: 599-611.

Meira, J.R. \& M.L. Porto. 1998. Reserva Biológica do Lami: a vida na beira do lago, p. 89-92. In: R. Menegat (Ed.). Atlas Ambiental de Porto Alegre. Porto Alegre, Editora Universidade Federal do rio Grande do Sul, 238p.

NAIR, G.A. 1998. Reproductive and population biology of Porcellio scaber (Isopoda, Oniscidea) in Benghazi, Libya. Israel Journal of Zoology, Jerusalem, 44 (3-4): 399- 412.

Noro, C. \& L. Buckup. 2003. O crescimento de Aegla leptodactyla Buckup \& Rossi (Crustacea, Anomura, Aeglidae). Revista Brasileira de Zoologia, Curitiba, 20 (2): 191-198.

Paoletti, M.G. \& M. Hassall. 1999. Woodlice (Isopoda: Oniscidea): their potential for assessing sustainability and use as bioindicators. Agriculture Ecosystem \& Environment, Amsterdam, 74: 157-165.

SANTOS, E.P. 1978. Dinâmica de populações aplicada à pesca e piscicultura. São Paulo, HUCITEC/EDUSP, XVIII+169p.

SNEDECOR, C.L. \& W.G. Cochran. 1967. Statistical Method. Ames, The Iowa State University Press, $6^{\text {th }}$ ed., 593p.

SutTon, S.L. 1968. The population dynamics of Trichoniscus pusillus and Philoscia muscorum (Crustacea: Oniscoidea) in limestone grassland. Journal of Animal Ecology, Oxford, 37: 425-444.

SutTon, S.L. 1970. Growth patterns in Trichoniscus pusillus and Philoscia muscorum (Crustacea: Oniscoidea). Pedobiologia, Jena, 10: 434-441.

Sutton, S.L.; M. Hassall; R. Willows; R.C. Davis; A. Grundy \& K.D. SuNDERLAND. 1984. Life histories of terrestrial isopods: a study of intra- and interespecific variation. In: S.L. SuTTON \& D.M. Holdich (Eds). The biology of terrestrial isopods. London, Symposium of The Zoological Society of London, 53: $269-294$.

Revista Brasileira de Zoologia 21 (1): 1-8, março 2004 
Sunderland, K.D.; M. Hassall \& S.L. Sutton. 1976. The population dynamics of Philoscia muscorum (Crustacea: Oniscoidea) in a dune grassland ecosystem. Journal of Animal Ecology, Oxford, 45: 487-506.

Valenti, W.C.; J.T.C. Mello \& V.L. Lobão. 1994. Maturation and growth curves of Macrobrachium carcinus (Linnaeus) (Crustacea, Decapoda, Palaemonidae). From Ribeira do Iguape River, southern Brazil. Revista Brasileira de Zoolo- gia, Curitiba, 11 (4): 649-658.

VON BERTALANFFy, L. 1938. A quantitave theory of organic growth (inquiries on growth laws). Human Biology, Detroit, 10 (2): 181-213.

WALFORD, L.A. 1946. A new graphic method of describing the growth of animals. Biological Bulletin, Woods Hole, 90: 141-147.

WARBURG, M.R. 1993. Evolutionary Biology of Land Isopods. Berlin, Springer-Verlag, 159p.

Received in 17.VI.2003; accepted in 11.I.2004.

Revista Brasileira de Zoologia 21 (1): 1-8, março 2004 